\title{
La búsqueda del sentido: enseñar y aprender Historia
}

Aurora Terán Fuentes

Yo soy yo y $\mathrm{mi}$ circunstancia, y si no la salvo a ella no me salvo yo.

José Ortega y Gasset

\section{Introducción}

La historia, así como su enseñanza y aprendizaje, tienen que ver con la construcción del sentido y la relación con el cuestionamiento: ¿para qué nos sirve? A la pregunta, ¿para qué estudiar Historia?, se expone la respuesta de tres grandes historiadores: Luis Villoro, Héctor Aguilar Camín y Enrique Florescano, quienes de una forma muy clara, invitan a tratar de comprender los fines de la historia. El objetivo central de este artículo es debatir sobre la historia, su enseñanza y aprendizaje; así como el sentido que se le debe conferir; además, se acompaña de una propuesta sencilla para trabajar con jóvenes.

\section{El aparente sinsentido de la historia}

La asignatura de Historia, a pesar de reformas, nuevos enfoques y esfuerzos individuales de algunos docentes, porta dos etiquetas: es confusa (por tantas fechas y nombres), y es aburrida; dichas etiquetas no son sencillas de quitar. Enrique Florescano (2000: 135) apunta que básicamente la enseñanza de la historia se rige todavía por la memorización. Leer y subrayar, hacer resúmenes, responder cuestionarios, y luego memorizarlos para el examen. Esto provoca que a los niños no les guste y no le encuentren un sentido.

Los datos hablan por sí mismos. Por ejemplo, aprovechando el contexto del año 2010, la prueba Enlace, con motivo de las conmemoraciones del Bicentenario de la Independencia y el Centenario de la Revolución, evaluó los conocimientos de Historia que tienen los niños, el resultado no fue muy alentador: 8 de cada 10 niños registraron un nivel insuficiente y elemental. Seguramente algunos niños y también jóvenes se hacen la tan temida pregunta: ¿Historia para qué? Los datos son un llamado de atención, reflejan resultados no deseados, reflejan una seria problemática que invita al debate, en el cual deben ser incluidos los mismos niños y jóvenes.

En este tema del sentido de la historia y de su enseñanza y aprendizaje, existe un libro clásico de título muy sugerente: Historia ¿para 
qué?, hay una ironía presente, porque parecería que la respuesta es: absolutamente para nada. Sin embargo, es un referente obligado, precisamente para el debate. En ese libro, Luis Villoro plantea una posición ampliamente compartida por los historiadores, en relación con que uno de los sentidos de la historia es la comprensión del presente, por lo tanto, es necesario fortalecer a través del relato histórico y la enseñanza de la historia los vínculos entre el pasado con respecto al presente, y el presente con respecto al pasado, para que el conocimiento de la historia no se vea como muerto, estático y descontextualizado; Villoro (2000: 46) responde a la pregunta "historia ¿para qué?":

Para comprender, por sus orígenes, los vínculos que prestan cohesión a una comunidad humana y permitirle al individuo asumir una actitud consciente ante ellas. Esa actitud puede ser positiva: la historia sirve, entonces, a la cohesión de la comunidad; es un pensamiento integrador; pero puede también ser crítica; la historia se convierte en pensamiento disruptivo: porque, al igual que la filosofía, la historia puede expresar un pensamiento de reiteración y consolidación de los lazos sociales o, a la inversa, un pensamiento de ruptura y de cambio.

Por su parte, Héctor Aguilar Camín (2000: 147), en el mismo libro, también responde a la pregunta, y proporciona varias respuestas:

Historia para atender las urgencias y preguntas del presente, para afianzar o inventar una identidad y reconquistar continuamente la certeza de un sentido colectivo o personal; la historia para dirimir las legitimidades del poder, para imponer o negar la versión de los vencedores, para rescatar o rectificar la de los vencidos. O para el ejemplo de la vida, para el repertorio infinito de la acción. Y al revés: historia para la contemplación paralítica y demorada, para el goce y la imaginación, para la curiosidad que pregunta simplemente por los trayectos de otros pueblos y otras civilizaciones. Historia también para saciar los rigores del largo y difícil camino de la ciencia, para recordar y comprender, para conocer y reconocer. En fin, historia para deshacerse del pasado, para evitar su acción incontrolada sobre las generaciones que la ignoran, para sustraerse al destino previsto por el aforismo de
Santayana según el cual los pueblos que desconocen su historia están condenados a repetirla.

Para cerrar, Enrique Florescano, en su libro Para qué estudiar y enseñar la historia (2000: 129-131), defiende la idea de que la historia permite el rescate de la memoria colectiva. Y plantea que las prioridades de la enseñanza de la historia deben ser:

- Proporcionarle a los niños y jóvenes conocimientos sobre geografía e historia para que interiorice la cultura nacional. Y así coadyuvar en forja de la visión de mundo del niño.

- Fomentar la curiosidad por nuestro pasado.

- Hacer sentir a los niños y jóvenes que los saberes de la historia constantemente se reinterpretan y discuten.

- Desarrollar la capacidad crítica.

- Hacer énfasis en la importancia por el conocimiento de otras naciones o pueblos.

- Utilizar como recursos ejemplos históricos para comprender el mundo contemporáneo.

\section{Partir del presente y el uso de fuentes primarias: una propuesta para trabajar con jóvenes}

La siguiente idea propone cómo trabajar con jóvenes del nivel medio superior o superior con una fuente primaria para analizar situaciones del pasado, y relacionar con el presente. Se toma como punto de partida la situación de violación a los derechos humanos, y se presenta el siguiente objetivo: documentar y contextualizar casos de violación de derechos humanos en diferentes contextos históricos de la segunda mitad del siglo xx, a partir de una fuente original, como es la Declaración Universal de los Derechos Humanos (ONU, 1948), para analizar temas como el de violencia, maltrato, marginación, migración, campos de refugiados, genocidio, entre otras problemáticas del mundo contemporáneo (el estudiante libremente elige el caso que quiere documentar; siempre y cuando sea después de la Segunda Guerra Mundial, tiempo que corresponde a la creación de la Organización de las Naciones Unidas). Tareas concretas por realizar: 
- Exponer situaciones contemporáneas de violación a los derechos humanos en diferentes partes del mundo. Investigar y documentar casos.

- Comentar la Declaración Universal de los Derechos Humanos.

- Realizar un periódico (uso de tecnologías de información y comunicación) que anuncie la Declaración, así como la crónica de casos de violación de derechos humanos.

- Debate sobre el antes y el después de la Declaración.

- Dialogar sobre los casos expuestos en relación con el tema de derechos humanos.

- Organizar una plenaria sobre la experiencia de aprendizaje.

Básicamente el planteamiento gira en torno al problema del sentido; por lo tanto, a través de tópicos de interés, estrategias y recursos. Lo que se busca es que el joven se involucre en las actividades de aprendizaje.

\section{Comentario final}

La historia se debe difundir, es un deber, porque es una herramienta fundamental para la transformación social, es un cimiento, una base sólida en la cual se puede edificar el edificio social; por lo tanto, la tarea para México es compleja y existe una deuda pendiente, sobre todo con los niños, niñas y jóvenes.

La frase de Ortega y Gasset: "Yo soy yo y mi circunstancia, y si no la salvo a ella no me salvo yo", es un recordatorio de lo que nos define, nos da identidad, y del peligro de perder el rumbo como individuos y como nación. La historia es parte fundamental de la formación humanística.

\section{Fuentes de consulta}

Aguilar Camín, H. (2000). Historia para hoy. C. Pereyra y otros, Historia ¿para qué? (pp. 145-168). México: Siglo xxi editores.

Florescano, E. (2000). Para qué estudiar y enseñar la Historia. México: Instituto de Estudios Educativos y Sindicales de América.

Organización de las Naciones Unidas. (1948). Declaración Universal de los Derechos Humanos. ONU. Recuperado el 10 de junio de 2013, de http://bit.ly/19M90fl.

Villoro, L. (2000). El sentido de la Historia. C. Pereyra y otros, Historia ¿para qué? (pp. 3352). México: Siglo XXI editores. 